\title{
ANÁLISE COMPARATIVA ENTRE AS SENSIBILIDADES DA REAÇÃO INDIRETA DE ANTICORPOS FLUORESCENTES E DA REAÇÃO DE SABIN-FELDMAN NA PESQUISA DE ANTICORPOS SÉRICOS PARA TOXOPLASMOSE $\left(^{*}\right)$
}

\author{
Sérgio Gomes Coutinho ** Carlos Mauricio de Andrade ** Gilsea Sarmento \\ Malvar $* * *$ e Luiz Fernando Ferreira $* * * * *$
}

284 soros provenientes de doadores de sangue no Rio de Janeiro, foram submetidos à reação de Sabin Feldman (R.S.F.) e à reação indireta de anticorpos fluorescentes (R.I.A.F.) para toxoplasmose.

Foram observados 37 resultados concordantes negativos, 216 resultados concordantes positivos e 31 resultados não concordantes quanto a positividade e negatividade, sendo que entre êstes últimos houve um maior número de resultados positivos na R.S.F. do que na R.I.A.F

A percentagem de resultados concordantes quanto a positividade ou negatividade foi de $89 \%$.

Entre os 216 sôros que reagiram em ambas as reações 143 apresentaram titulos identicos, o que representa uma proporção de $66,2 \%$. Se forem consideradas como concordantes ou títulos positivos diferentes em apenas uma dilução ao quádruplo, a proporção de resultados positivos concordantes atinge a cêrca de $99 \%$.

Os presentes resultalos confirmaram o estreito paralelismo entre as duas reações, podendo a R.I.A.F. ser utilizada rotineiramente para o diagnóstico scrológico da toxoplasmose.

\section{INTRODUC̣ĀO}

Entre os testes utilizados para o diagnóstico sorológico da Toxoplasmose, a reação de Sabin-Feldman deve ser, segundo Betz (2), considerada como básica, servindo de referência para a comparação de outras técnicas diagnósticas. De acôrdo com Feldman (11), é ainda o sistema mais específico e sensivel para medir anticorpos para Toxoplasmose. Apresenta entretanto alguns inconvenientes que vários autores já chamaram a atenção e que se referem principalmente a utilização do toxoplasma vivo e a necessidade do "fator accessório".

A partir dos trabalhos de Coons e col. (7), a utilização de anticorpos fluorescentes como técnica diagnóstica foi sendo difundida, tendo Goldman $(15,16,17)$ idealizado a sua aplicação para o diagnóstico

Trabalio do Departamento de Ciencias Biológicas da Fundaça Fo Fino Fspecializado de Saúde Pública (FENSP)

Professor Adjunto - Departamento de Ciências Biológicas.

Auxiliar de Ensino - Departamento de Ciências Biologricas.

Assistente de Ensino - Departamento de Estatistica FENSP

Chefe do Departamento de Ciências Biológicas - Professor Titular de Parasitologia

Recebido para publicaçào em $6-4 \cdot-70$. 
da Toxoplasmose, utilizando um teste baseado na inibicão da fluorescência específica

Trabalhos subsequientes de Kelen e cols. (18) e Camargo (4), verificaram que a técnica de inibicão da fluorescência empregada por Goldman 116,17 ) não oferecia resultados tão satisfatórios quanto a técnica indireta de anticorpos fluorescentes desenvolvida por Weller e Coons (28).

Esta última técnica com algumas modificações vem sendo utilizadas por diversos autores.

Entre as vantagens da reação indireta de anticorpos fluorescentes (R.I.A.F.) sôbre a reação de Sabin-Feldman (R.S.F.) coloca-se a possibilidade de utilizaçāo de toxoplasmas mortos como antigenos e de tornar dispensável o "fator accessório". De outro lado, uma das grandes dificuldades da R.I.A.F., a utilização de conjugados fluorescentes de antigamaglobulina, vem sendo superada pela possibilidade de serem adquiridos no comércio, conjugados de boa qualidade. Entretanto, uma das limitaçōes da R.I.A.F., refere-se à necessidade de microscopia com fonte de iluminação ultra-violeta, o que pode constituirse em um obstáculo para a realicação da reação.

No entanto, o que dificulta realmente tanto o emprêgo do R.S.F. como da R.I.A.F. em maior número de laboratórios, refere-se à necessidade do emprêgo do toxoplasma vivo ou recentemente morto e mantido em "freezer", conforme a reação que se empregar. Assim sendo, é necessário manter o protozoário em laboratório seja por intermédio de repiques da cepa em peritôneo de camundongo, seja por intermédio de outras técnicas menos frequientemente utilizadas, mas sempre empregando-se tecido vivo, uma vez que o toxoplasma é um parasito que só pode ser cultivado na célula viva .

No entanto, com relação a R.I.A.F, existe a possibilidade dêste inconveniente vir a ser em parte superado, tendo em vista os trabalhos de Takumi e cols. (25) e Coudert e cols. (8) que empregaram um liofilizado de toxoplasmas como antigeno, na técnica de imunofluorescência indireta, obtendo bons resultados, sendo que Takumi e cols. (25) encontraram resultados comparáveis as do teste de hemaglutinação .
No presente trabalho são comparados resultados obtidos pelo R.S.F. e R.I.A.F. com objetivo de obter-se uma experiência sôbre a sensibilidade desta última reação. uma vez que se pretende utilizá-la em trabalhos mais amplos sôbre a Toxoplasmose na região $(10)$

\section{MAT̄ERIAL E MÉTODOS}

Foram utilizados 284 sôros provenientes de doadores de sangue do Instituto de Hematologia Artur de Siqueira Cavalcanti do Rio de Janeiro para a comparação entre a reação de Sabin e Feldman e a reação indireta de anticorpos fluorescentes para o diagnósticc sorológico da Toxoplasmose.

o sangue para exame sempre foi coletado pela manhã, estando os doadores em jejum. Cêrca de 2 a 3 horas após, os sôros eram separados e mantidos à $-20^{\circ} \mathrm{C}$ durante 1 a 5 dias até ser realirada a R.I.A.F. e R.S.F. Em geral uma das reaçóes era efetuada com intervalo de um a très dias da outra, sem que se tivesse conhecimento da primeira quando se efetuasse a segunda.

Técnicas das reações:

\section{a) Reação de Sabin e Feldman.}

Utilizou-se a técnica original de Sabin e Feldman $(21,22$ ) com pequenas modificaçōes, e que já havia sido empregada em trabalho anterior (9).

Para obter-se os toxoplasmas, injetou--se $3 \mathrm{ml}$ de solução de citrato de sódio a $3,8 \%$ por via intraperitoneal em camundongo com dois dias de infeccão e a seguir aspirou-se o líquido peritoneal, rico em Toxoplasma gondii.

Os sôros utilizados como fator accessório foram provenientes na maioria das vêzes de adultos jovens, funcionários da Instituição a que pertencemos, já testados anteriormente, demonstrando funcionar convenientemente, sem que houvesse necessidade dos sôros serem diluidos.

A solução corante foi preparada no momento da reação, juntando-se $1,5 \mathrm{ml}$ de solução alcoólica saturada de azul de metileno, $1 \mathrm{~g}$ de azul de metileno em $65 \mathrm{ml}$ de álcool anidro) a $5 \mathrm{ml}$ de solução tam- 
pão pH ... 11. Esta última solucão teve a seguinte constituição:

Carbcnato de sódio a $0,53 \% \ldots \ldots .73 \mathrm{ml}$ Borato de sódio a $1,91 \% \_-0,27 \mathrm{ml}$

Os sôros dos doadores de sangue a serem examinados foram diluídos em solucão aquosa de cloreto de sódio a $0,85 \%$ a partir da diluição $1: 16$ e a seguir sucessivamente $1: 64,1: 256,1: 1024,1: 4096$.

Colocou-se em tubos $0,1 \mathrm{ml}$ de cada uma destas diluições as quais juntou-se $0,1 \mathrm{ml}$ de uma mistura de uma parte de exsudato peritoneal de camundongos com 2 dias de infecção e quatro partes de fator accessório. Os tubos após serem arrolhados eram levados ao banho-maria a $37^{\circ} \mathrm{C}$ durante uma hora. Em seguida eram colocados em geladeira a $4^{\circ} \mathrm{C}$ e posteriormente retirados parceladamente no momento de ser efetuado o teste do corante.

Juntou-se, então, a cada tubo, cêrca de $0,02 \mathrm{ml}$ da solução corante tamponada de azul de metileno e após misturar-se bem e deixar em repouso por 5 minutos, retirou-se uma gôta da mistura e cclocou-se entre lâmina e laminula para ser efetuada a leitura microscópica com aumento de 460 vêzes. Eram então contados 50 toxoplasmas extracelulares, e as diluicōes eram consideradas positivas, quando mais de $50 \%$ dos protozoários apresentassem-se não corados

No caso de contagens muito aproximadas de elementos corados e não corados, aumentou-se até 100 o número de organismos observados.

O título do sôro examinado foi dado pela maior diluição em que ainda predominassem as formas não coradas. No caso de sôro positivo na diluição de 1 : 4096, repetiu-se a reação no dia seguinte a partir da diluição 1:4000 e em múltiplos de 2 até $1: 32000$.

$\mathrm{Em}$ tôdas as vêzes que se realizou a reação, teve-se o cuidado de fazer-se concomitantemente uma reação com sôro positivo de título já conhecido, e também o teste negativo. Para êste último junton-se $0,1 \mathrm{ml}$ de solução de cloreto de sódio a $0,85 \%$, a $0,1 \mathrm{ml}$ da mistura $1: 4$ de exsudato peritoneal mais fator accessório. Os procedimentos subseqüentes obedeceram a mesma técnica da reação sendo que na contagem dos organismos corados e não corados deviam predominar os corados em proporção igual ou superior a $90 \%$.

b) Reaçāo indireta de anticorpos fluorescentes:

A técnica empregada, foi a utilizada por Camargo (5) e Nery-Guimarães (20), ccm algumas modificaçōes. Os toxoplasmas utilizados como antigeno foram obtidos de exsudato peritoneal de camundongo, da mesma maneira empregada para a reação de Sabin e Feldman.

Ao exsudato peritoneal com citrato de sódio a $3,8 \%$, acrescentou-se igual quantidade de solução contendo $2 \%$ de formalina em solução salina tamponada $\mathrm{pH} 7,2$, deixando-se a mistura em repouso com agitação ocasional por 30 minutos. Esta scluçāo tamponada era preparada em estoque, 20 vêzes concentrada, para ser diluida em água destinalada conforme as necessidades de uso.

No preparo da solução estoque foi obedecida a seguinte composição:

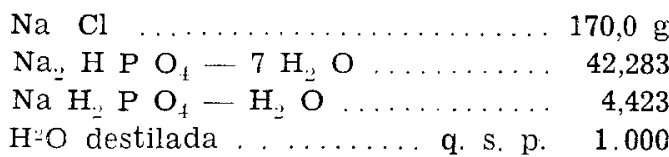

Após os 30 minutos de repouso, o material rico em toxoplasmas, era centrifugado a 500 r.p.m. durante 5 minutos, para a sedimentação dos leucócitos e a seguir o sobrenadante era centrifugado a 2.000 r.p.m. durante 10 minutos para concentrar os toxoplasmas. Êstes eram então suspensos em uma quantidade de solução de cloreto de sódio a $0,85 \%$ suficiente para conseguir-se uma boa concentração dos protozoários nos esfregaços em que seriam feitas as reações. A primeira centrifugacão a 500 r.p.m. permitiu que os preparados ficassem quase totalmente livres de leucócitos.

Com esta suspensão de toxoplasmas eram feitos esfregaços em lâminas bem limpas por intermédio de fervura em solução detergente, imersão por 24 horas ou mais em álcool etílico a $90^{\circ}$, lavagem em água destilada e finalmente as lâminas eram flambadas. Muitas vêzes era feito novo esfregaço sôbre o primeiro, para conseguir-se uma concentração suficiente de 
toxoplasmas por campo microscópico. Com o segundo esfregaço sêco em temperatura ambiente eram feitos sôbre êles dois grupos de cinco retângulos de aproximadamente $5 \mathrm{~mm}=$ cada um, utilizando-se esmalte de unha. Em cada grupo de cinco retângulos, colocou-se as diluições de cada sôro a ser testado, já inativado a $56^{\circ} \mathrm{C}$ por 30 minutos. As diluições do sôro era:n feitas em solução de cloreto de sódio a $0,85 \%$ a partir de $1: 16$ e sucessivamente em múltiplos de quatro até $1: 4096$. Quando necessário, continuou-se a dilução a partir de 1:4000 e sucessivamente em múltiplos de 2 até $1: 32.000$. Aproximadamente $0,01 \mathrm{ml}$ de cada diluição era pipetado nos respectivos retângulos sôbre o esfregaço e uma vez colocadas as lâminas em câmara úmida, eram levadas à estufa a $37^{\circ} \mathrm{C}$ durante uma hora, para processar-se a primeira fase da reação antígenoanticorpo.

Terminada esta etapa, as gotículas das diluições dos sôros sôbre os esfregaços eram desprezadas e as lâminas submetidas a dois processos de lavagem, durante 10 minutos cada um, imergindo-se as lâminas em duas trocas da solução salina tamponada com fosfatos, a mesma já descrita anteriormente.

Depois da lavagem, cada retângulo foi cuidadosamente sêco com papel de filtro evitando-se movimentos mais bruscos que pudessem prejudicar a preparação.

Uma vez sêcos, cada retângulo era preenchido com aproximadamente $0,01 \mathrm{ml}$ do conjugado antigama globulina humana ( Ig $G$ humana) -isotiocianato $e$ fluoresceina, fabricado por Microbiological Ass. Inc.. As preparações eram novamente colocadas em câmara úmida e levadas à estufa a $37^{\circ} \mathrm{C}$ durante uma hora para processar-se a segunda fase da reação anticorpo-antianticorpo conjugado com isotiacianato de fluoresceina.

Após êste tempo, desprezou-se o excesso do conjugado fluorescente sendo as lâminas submetidas a dois processos de lavagem de 5 minutos cada um, por imersão em duas trocas da solução salina tamponada com fosfatos, $\mathrm{pH}$ 7,2. As lâminas eram novamente sêcas, principalmente as áreas limitadas pelos retângulos, usando-se papel de filtro com os cuidados já ci- tados para evitar-se dano nas preparacões. A seguir as lâminas eram montadas colocando-se uma lamínula cobrindo cada grupo de cinco retângulos tendo-se anteriormente pipetado uma gôta de solução tamponada de glicerina sôbre cada grupo de retângulos.

As lâminas assim preparadas eram examinadas no mesmo dia, em um aumento de 400 vêzes, utilizando-se equipamento Wild com fonte de iluminação ultravioleta fornecida por lâmpada de vapor de mercúrio HBO-200.

Os títulos dos sôros desconhecidos eram dados pela maior diluição em que a maioria dos toxoplasmas ainda apresentasse nitida fluorescência de tonalidade esverdeada, em tôda a sua periferia. Nas reações negativas os toxoplasmas eram distinguíveis contra o fundo escuro, apesar de não apresentarem fluorescência evidente em tôda a sua periferia. Em cada grupo de reações sempre incluiu-se um sôro positivo de título conhecido e outro de titulo negativo para que a técnica es. tivesse sendo sempre testada. Èstes sôros contrôles foram selecionados entre aqueles que haviam apresentado títulos idênticos tanto pela reação de Sabin Feldman como pela reação de imunofluorescência indireta.

Em ambas as reações, os sôros foram considerados negativos quando não reagiram na diluição de $1: 16$.

\section{RESULTADOS}

O exame pelas reaçōes de Sabin e Feld. man e reação indireta de anticorpos fluorescentes de 284 sôros provenientes de doadores de sangue, evidenciou os seguintes resultados:

Inicialmente, levando-se em conta apenas resultados negativos e positivos, não importando o título entre êstes últimos, cbservou-se a seguinte distribuição:

Resultados concordantes negativos em 37 casos

Resultados concordantes positivos em 216 casos.

Resultados não concordantes quanto ia positividade e negatividade em 31 casos

cbservaram-se assim 253 resultados concordantes positivos e negativos em um total de 284 sôros examinados o que representa uma percentagem de $89,08 \%$ 
Entretanto, o cáiculo dos resultados concordantes pode tornar-se mais preciso se forem retirados os 37 casos negativos em ambos os métodos, pois em qualquer técnica de menor sensibilidade, êstes resultados seriam negativos, e portanto concordantes, o que poderia falsear a comparação entre os métodos.

Assim sendo, foram encontrados 216 resultados concordantes positivos em um total de 247 casos com uma proporção de concordância de $87,4 \%$, que ao nivel fiducial de $5 \%$ está contida no intervalo de confiança de $83,5 \%$ e $91,3 \%$.

Dos 31 casos nāo concordantes quanto à negatividade e rositividade, verificou-se:

R.S.F. positiva e R.I.A.F. negativa em 22 casos.

R.S.F. negativa e R.I.A.F. positiva em 9 casos.

Houve portanto um maior número de resultados positivos em R.S.F. do que em R.I.A.F., sendo que esta diferenca mostrou-se estatisticamente significante em um nivel fiducial de $5 \%$, quando analisada pelo teste de proporções: $\mathrm{t}$ calculado = 2,335 maior que $\mathrm{t}$ tabelado $=1,645$.

Se entretanto levar-se em conta os resultados, não sòmente quanto a negatividade ou positividade mas também quanto à variação dos títulos entre os positivos, cs 284 doadores passam a ser distribuidos segundo o quadro $I$.

Neste quadro estāo grifados os números referentes à quantidade de casos que apresentaram títulos positivos identicos em ambas as reaçoses, o que representa um total de 143 casos.

Sendo assim, do total de 126 sôros que reagiram em ambas as técnicas, 143 apre-. sentaram títulos idênticos o que representa uma proporção de $66.2 \%$ ciue está contida no intervalo de confianca de $59,9 \%$ a $72,4 \%$ com um nivel fiducial de $5 \%$. Se entretanto considerarmos como ccncordantes tanto os resultados identicos como os diferentes em apenas uma diluiçāo, a proporçāo de concordância entre os resultados positivos sobe a cêrca de $99 \%$.

Como já foi visto, foram encontrados 143 títulos idênticos e portanto 104 títulos

Q UADRO I

DISTRIBUIC̣ÃO DOS 284 DOADORES DE SANGUE SEGUNDO O TÍTULO DAS REAÇOEES DE ANTICORPOS FLUORESCENTES E DE SABIN E FELDMAN

\section{REAÇ̃̃O INDIRETA DE ANTICORPOS FLUO- RESCENTES TITTULOS}

SABIN E FELDMAN

\section{TITULOS}

TOTAIS

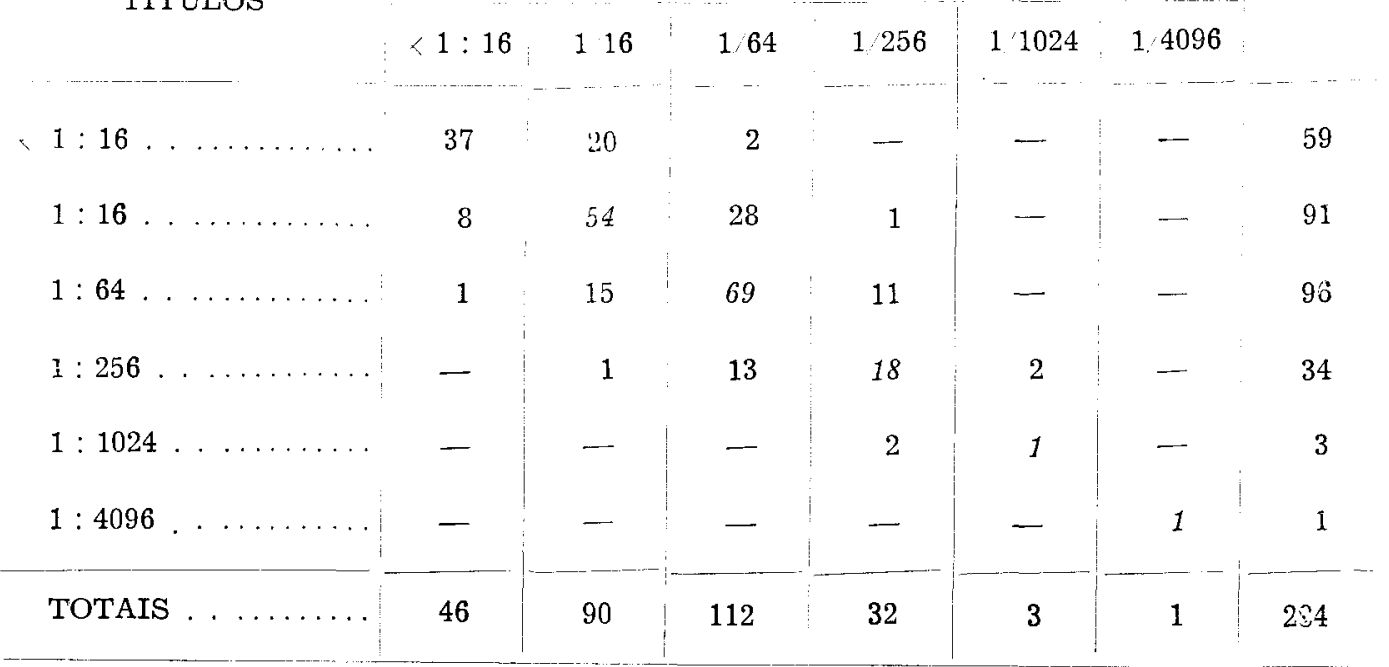


diferentes nas duas reaçoes, entre os 247 sôros que reagiram em ambas as temicas ou em apenes uma delas. O quadro in expressa a distribuição dêsses 104 casos de titulos diferentes, quanto ao sentido da diferença. isto é. se o título observado em R.S.F. foi maior que o observado en R.I.A.F. ou vice versa. Neste mesmo quadro, os casos também estão separados quanto a magnitude das diferenças observadas entre os resultados das duas reações: Na Tabela $A$ as discrepâncias em apenas um tubo das diluições e na tabela $B$ as discrepancias em dois tubos.

Para verificar se entre os casos de resultados diferentes uma das reacōes apresentou resultado significantemente mais elevado que a outra, foi aplicado o teste estatistico de diferença de proporçōes. Entretanto, dos 104 casos a serem analisados, os 5 casos em que as discrepancias foram mais intensas, (quadro II Tabela B) não permitem uma análise estatística, pois o número de cbservacōes foi muito pequeno. No cntanto, nestes 5 casos pareceu não ter havido tendência de qualquer das duas reacōes a apresentar resultados mais elevados com maior freqüência, pôsto que en 3 casos R.S.F. apresentou o título mais elevado $e$ em 2 casos a R.I.A.F. foi que aprosentou o titulo mais elevado.

Dos 99 casos restantes, quadro II $\mathrm{Ta}-$ bela A, em 61 dêles a R.S.F. apresentou resultado mais elevado que a R.I.A.F. e ilos outros 38, a R.I.A.F. apresentou mais elevado que a R.S.F. Para que esta diferenca entre a R.S.F. e a R.I.A.F. não fôsse significante seria necessário que em $50 \%$ dos casos, a R.S.F. apresentasse o titulo superior e nos outros $50^{\circ}$ c a R.I.A.F. apresentasse o título superior. No entanto, êste fato não ocorreu pois os 61 casos em que a R.S.F. apresentou titulo superior à R.I.A.F., representam mais de $50 \%$ des 99 casos observados. O teste de diferença de proporcões demonstrou ser signi-

QUADRO I I

DISTRIBUIÇÃO DOS CASOS QUE APRESENTARAM RESULTADOS DIFERENTES EM R.S.F. E R.I.A.F., QUANTO AO SENTIDO DA VARIACĀO (R.S.F. MAIOR QUE R.I.A.F. OU VICE VERSA). OS CASOS AINDA ESTÃO DIVIDIDOS EM DUAS TABELAS "A" E "B", QUANTO A MAGNITUDE DA DISCREPÂNCIA ENTRE R.S.F. E R.I.A.F.

\begin{tabular}{|c|c|c|c|c|}
\hline & $\begin{array}{c}\text { Faixa em que se verificou a } \\
\text { discordância entre R.S.F. } \\
\text { e R.I.A.F }\end{array}$ & $\begin{array}{l}\text { R.S.F. maior } \\
\text { que R.I.A.F. }\end{array}$ & $\begin{array}{l}\text { R.I.A.F. maior } \\
\text { que R.S.F. }\end{array}$ & TOTAL \\
\hline \multirow{3}{*}{$\begin{array}{l}\mathrm{T} \\
\mathbf{A} \\
\mathbf{B} \\
\mathbf{E} \\
\mathbf{L} \\
\mathbf{A}\end{array}$} & $<1: 16-1: 16$ & 20 & 8 & 28 \\
\hline & $1: 16-1: 64$ & 28 & 15 & 43 \\
\hline & $1: 64 \quad-1: 256$ & 11 & 13 & 24 \\
\hline \multirow[t]{2}{*}{ " $A$ " } & $1: 256-1: 1024$ & 2 & 2 & 4 \\
\hline & Total Parcial & 61 & 38 & 99 \\
\hline \multirow{3}{*}{$\begin{array}{l}\mathrm{T} \\
\mathrm{A} \\
\mathrm{B} \\
\mathrm{E} \\
\mathrm{L} \\
\mathrm{A}\end{array}$} & $<1: 16-1: 64$ & 2 & 1 & 3 \\
\hline & $1: 16-1: 256$ & 1 & 1 & 2 \\
\hline & Total Parcial & 3 & 2 & 5 \\
\hline$" B "$ & TOTAL . . & 64 & 40 & 104 \\
\hline
\end{tabular}


ficante esta diferença. sendo maior a frequiencia de resultados mais elevados na R.S.F. do que na R.I.A.F. posto que o t calculado - 2,312 fci superior ao t tabelado - 1,645, para um nível fiducial de $5 \%$

Pode-se ainda observai pelo quadro II Gue a predominancia de resultados mais elevados na R.S.F. do que na R.I.A.F. foi mais significante nas diluiçoes mais baixas, quando as diferenças encontradas estavam entre resultados negativos e positivos a 1:16 e entre os resultados positivos a $1: 16$ e 1:64 (t calculado -- 2,268 e 1.982 respectivamente)

\section{COMENTÁRIOS}

Das várias técnicas utilizadas para o diagnóstico sorológico da toxoplasmose, a R.I.A.F. vem send outilizada em vários laboratórios, principalmente por ser bastante prática e de fácil manêjo, sem representar maior risco de constituir-se em fonte de infecção toxoplásmica para aquêles que a manuseiam.

No quadro III estão, resumidos os resultados encontrados por vários autores que utilizaram a R.I.A.F. comparando-a com a R.S.F.

Apesar das variações entre as técnicas utilizadas na R.S.F. e principalmente na R.I.A.F. os resultados podem ser considerados como passíveis de comparação. Entre as variações na técnica da R.I.A.F. destaca-se o tempo de incubação a $37^{\circ} \mathrm{C}$ para processar-se a reação antigeno anticorpo, que variou de 15 minutos a 1 hora segundo os autores.

Os conjugados fluorescentes utilizados, também foram de origem diferente para quase todos os autores, assim como variou em maior ou menor grau a técnica de preparo do antigeno. Êste último foi preparado na maioria das vêzes a partir do líquido peritoneal de camundongos infectados. Boisseau e cols. (3) o utilizou em suspensão e não depois de sêco em lâminas como a maioria dos autores. Por outro lado, Betz (2) utilizou toxoplasmas em culturas de tecido e Van Nunem e col. (26) usaram cortes em criostado de cérebro de camundongos inefctados pelo Toroplasma gondii, como antigeno para a R.I.A.F

O sôro para pesquisa de anticorpos foi de origem humana, exceto os utilizados por Suzuki e cols. (24) aue eran provenientes de porcos.

Apesar destas variaçoes além de outras. na técnica da R.I.A.F. os resultados resumidos no quadro III polem ser considerados como concordantes dentro de limites estreitos. Neste quadro, incluimos nossos resultados concordantes negativos no conjunto dos resultados concordantes, para que pudessem ser comparados com os encontrados pela maioria dos autores citados. Sendo assim, as percentagens dos resultados concordantes quanto a negatividade e positividade variaram segundo os autores de $73,5 \%$ a $100 \%$. A percentagem de concordância mais baixa foi encontrada por Kelen e cols. (18) e poderia estar relacionada segundo Camargo (4) com o tempo de incubação a $37^{\circ} \mathrm{C}$, de apenas 30 minutos, que utilizaram na técnica da R.I.A.F.

Kelen e cols. (18) encontrando 159 sôros negativos na R.I.A.F. e positivos na R.S.F. e apenas 4 sôros positivos na R.I.A.F. e negativos na R.S.F., acreditam que seus resultados falam a favor dos que expressam dúvida sôbre a validade da R.S.F. especialmente sôbre a interpretação dos títulos abaixos. Entretanto, as discordâncias entre os resultados positivos e negativos encontradas por outros autores nunca foram tão intensas quanto as observadas por Kelen e cols. (18).

Nossos resultados evidenciaram que apesar de uma alta correlação entre resultados positivos e negativos nos dois métodos, que atingiu o intervalo de confiança de $82,7 \%$ a $91 \%$, os poucos resultados discordantes apresentaram um número significantemente maior de resultados positivos na R.S.F. do que na R.I.A.F.

Deve-se ainda ressaltar que dos $31 \mathrm{ca}$ sos em que houve discordância entre resultados negativos e positivos, em 28 dêles esta discordância ocorreu entre o resultado negativo e a primeira diluição positiva $-1: 16$. 

Q U A D R O I I I

SUMÁRIO DOS RESULTADOS ENCONTRADOS POR DIVERSOS AUTORES QUANDO COMPARARAM A REACÃO DE SABIN E FELDMAN (R.S.F.) E A REAÇÃO DE IMUNOFLUORESCENCIA INDIRETA (R.I.A.F.) PARA O DIAGNOSTICO SOROLÓGICO DA TOXOPLASMOSE

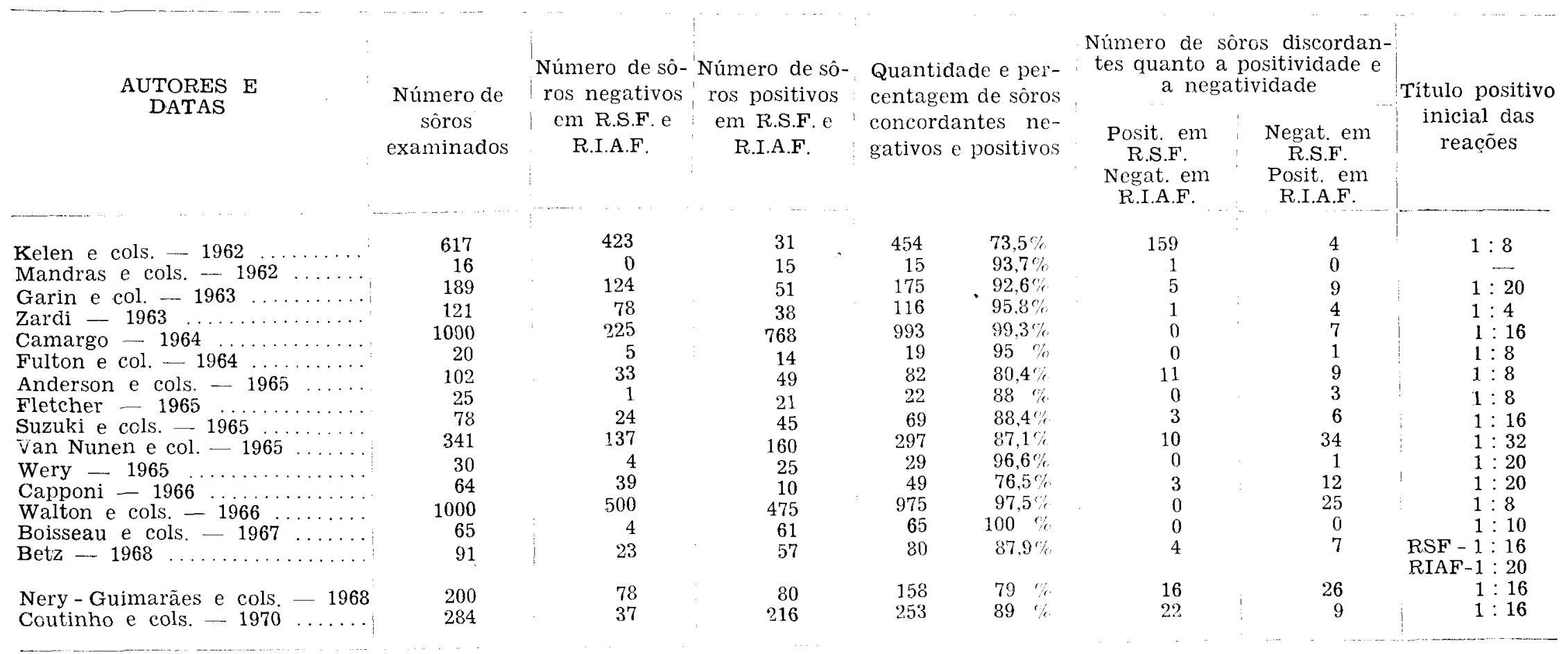


Van Nunen e col. (26) e Wery (29) além de outros, referem resultados semelhantes sendo que Camargo (4), encontrou 7 sôros com resultados discrepantes, todos negativos na R.S.F. e positivos na R.I.A.F. na diluição mais baixa $1: 16$.

Também entre os 216 sôros que reagiram em ambas as técnicas, a proporção de resultados idênticos. contida no intervalo de confiança de $59,7 \%$ e $72,2 \%$ é bastante elevada, tornando-se ainda mais nítido o paralelismo entre as duas reações so forem considerados como concordantes os sôros que apresentaram resultados diferentes por aperas um tubo de diluicão. Neste caso a proporcão de resultados considera. dos concordantes atingiria a mais de $99 \%$. A comparação dêstes resultados com os de cutrcs autores, nem sempre é fácil porque muitas vêzes o intervalo entre as diluicões dos sôros foram feitas em múltiplos de 2. outras vêzes em múltiplos de 4 como em nosso material. Também a diluição inicial do sôro considerada positiva variou de autor para autor. Entretanto, em uma revisão feita por Nery-Guimarāes e cols. (20), a percentagem de títulos coincidentes ou diferentes por apenas uma diluição, variou segundo os autcres de $50 \%$ a $100 \%$.

Nossos resultados entre os sôros positivos nas duas reações, evidenciaram que ao lado da alta percentagem de títulos idênticos, os riculos diferentes, quando ocorreram, o, foram com maior freqüência entre as diluições mais baixas.

Outros autores também encontraram o maior número de discrepâncias entre as duas reações nas diluiçoes mais baixas, e resultados superponiveis nas diluições mais elevadas. Kelen e cols. (18) observaram boa concordância nas diluições de 1:1024 ou superiores. Segundo Garin e col. (14) a especificidade dos testes são indiscutíveis nas diluições altas. Fletcher (12) evidenciou boa concordância principalmente nos sôros de títulos elevados, sendo que nas diluições baixas, o título encontrado na R.I.A.F. era inferior às vêzes em uma ou duas diluições ao dôbro. Nery-Guimarães e cols. (20) referem que o maior número de discrepâncias ocorreu nas diluições mais baixas, principalmente $1: 16$. Entretanto, êstes autores assim como Mandras e cols. (19), Zardi (30), Camargo (4), Ful- ton e col. (13), Suzuki e cols. (24) e Betz (2) são de opinião que os resultados dâ R.I.A.F. e R.S.F. são pràticamente superponiveis. Capponi (6) e Walton e cols. (27) acreditam que a R.I.A.F. possa ser mais sensivel, sendo que êste último observou em seus resultados que tôdas as discrepâncias maiores de uma diluição ao quádruplo foram com a R.I.A.F. positiva na maior diluição. Por outro lado, Van Nunem e col. (26) e Wery (29) observaram que a R.S.F. parece ser discretamente mais sensivel que a R.I.A.F.

Ncssos resultados também demonstraram o estreito paralelismo entre as duas reaçōes, mas com uma certa tencência da R.S.F. apresentar título mais elevado que a R.I.A.F. nas diluições mais bajxas.

Boisseau e cols. (3) além de realçar o valor diagnóstico da R.I.A.F. apesar de algumas discordâncias com a R.S.F. na altura do ritulo, observaram em infecção experimental de coelhos, que o título da R.I.A.F. no início da infecção era muito superior ao da R.S.F. e que com o equilíbrio da dcença êste passava a apresentar-se superior a R.I.A.F. Acreditam que èste dado possa vir a estabelecer a fase da doença, se aguda ou já em período crônico.

Vale a pena realçar que quanto à especificidade da técnica de imunofluorescência, esta já foi bem demonstrada desde o trabalho inicial de Goldman (16) e a seguir também por Kelen e cols. (8), Fulton e col. (13) e Fletcher (12), A reprodutibilidade da R.I.A.F. foi constatada tanto por Camargo (4) como Van Nunem e col. (26) e mais particularmente por sulzer e col. (23), que a consideraram comparável a da R.S.F.

\section{AGRADECIMENTOS}

Os autores agradecem a colaboração prestada por funcionários do Instituto de Hematologia Arthur de Siqueira Cavalsanti na coleta do material e principalmente ao Diretor daquele Instituto, Gen. Med. João Maia Mendonça, pelas facilidades que nos proporcionou.

Agradecemos também aos laboratórios Roche S/A pelo fornecimento dos conjugados fluorescentes. 


\section{SUMMARY}

284 sera from blood donors in Rio do Janeiro, were submited to the SabmFeldman reaction $(R S F$, and to the indirect fluorescence antibody $R I A F$, reaction for toxoplasmosis

In both reactions, 37 negative results were observed, 216 positive results and 31 results were positive by one lest and negative by the othor. Amsing these last results, there were more positive results by $R S F$ than bu $R I A F$. The percentage of agreement of the positive or negative results in both reactions lias 89 ?

Among 216 sera that reacted by both tests. 143 showed identica? titres that represented a proportion of $66.2^{\%}$. Positive titres that were different by coly one quadruple dilution being taken into consideration, the proportion of agreement among these positive results increased to approximately $99 \%$

The present results confirm the close parallelism between the two reactions; the RIAF can be used as a routine for the sorological diagnosis of loxcplasmosis.

\section{BIBLIOGRAFIA}

1 - ANDREONI, G., CURATOLO, D.. ROCCHI, G., TOSTI, U., VELLI, V. - La diagnosi sierológica di Toxoplasmosi mediante il test indiretto di immunofluorescenza. - Giorn. Mal. Inf. Parass. 17: 144, 1965.

2 - BETZ, A. - Diagnostic serologique de la Toxoplasmose au moyen d'antigenes prépares sur cultures cellulaires. - Bull. Wld. Hlth. Org. 39: $367,1968$.

3 - Boisseau, M., MOUlinier, C., De JOIGNY, C. - Immunofluorescence sur suspension de Toxoplasmes, comparaison avec le test de lyse - Bull. Soc. Path. Exot. 60: 205, 1967.

4 - CAMARGo, M. E. - Estudo comparativo das reaçóes de Sabin-Feldman e de imunofluorescência indireta, para a Toxoplasmose, em 1000 sôros humanos. Comportamento anômalo de alguns sôres. - Rev. Inst. Adolfo Lutz 24: 1, 1964.

5 - CAMARGO, M. E. - Preparation of microscopical slides to simplify immunofluorescence serological titrations. - Rev. Inst. Med. Trop. São Paulo 7: 39, 1965.

6 - CAPPONI, M. - Constatations personelles pour le diagnostic serologique de la toxoplasmose pour l'immunofluorescence - Bull. Soc. Path. Exot. 59: 77, 1966.

7 - COONS, A. H., KAPLAN, M. H. Localization of antigen in tissue cells. II Improvements in a method for the detection of antigen by means of fluorescent antibody. - J J. Exp. Med. 91: 1, 1950.
8 -- COUDERT, J., GARIN, J, P., AMBROISE THOMAS, T., KIEN TRUONG, T., RIGAUD, A., POTHIER, M. A., GEORGET. J. P. - Les antigènes lyophilisés en immunofluorescence, resultats preliminaires et perspectives d'avenir. - Bull. Ass. Dipl. Microbiol. Nancy - $\mathrm{N}^{\prime}$ 109: 9 , 1968 .

9 - COUTinho, S. G.. ANDRAde, C. M., LOPES, A. C., CHIARINI, C. FERFEIRA, L. F. - Observaçóes sôbre a presença de anticorpos para Toxoplasma gondii, em cães de área suburbana do Rio de Janeiro. - Rev. Soc. Bras. Med. Trop. 2: 285, 1968.

10 - COUTINHO, S. G., ANDRADE, C. M., FERREIRA, L. F. - Tentativa de isolamento do Toxoplasma gondii do sangue de doadores no Rio de Janeiro. A ser publicado.

11 - FELDMAN, H. A. - Toxoplasmosis - New England J. Med. 279: 1370, 1968 .

12 - FLETCHER, S. - Indirect Fluorescent Antibody Technique in the serology of Toxoplasma gondii. - $\mathrm{J}$. Clin, Path. 18: 193, 1965.

13 - FULTON, J. D., VOLLER, A. -- Evaluation of immunofluorescent and direct agglutination methods for detection of specific Toxoplasma antibodies. - Brit. Med. J. 2: 1173, 1964.

14 - GARIN, J. P., AMBROISE THOMAS. P. - Le diagnostic serologique de la Toxoplasmose par la methode des anticorps fluorescents (technique indirecte) - Presse Medicale 71: 2485, 1963. 
15 - GOLDMAN, $M$-.. Straining Toroplasma gondit with fluorescein labelled antibody. I The reaction in smears of peritoneal exudate _- J Exp. Med. 105: 549. 1957.

16 - GOLDMAN, M. - Staining Toxoplasma gondii with fluorescein -. labelled antibody. II A new serologic test for antibodies to Toxoplasma based upon inhibition of especific staining. -- J. Exp. Yed. 105: 557,1957

17 -- GOLDMAN, M. GORDON, M. A. CARVER, R. K. - Comparison of titers of dye and fluorescence inhibition test in the serologic diagnosis of Toxoplasmosis - Amer. $\mathbf{J}$. Clin. Path. 37: 541, 1962.

18 - KELEN, A. E., AYLLON-LEINDL, L.. IABZOFFSKY, N. A. - Indirect fluorescent Antibody method in serodiagnosis of Toxoplasmosis, - Canad. J. Microbiol. 8: 545, 1962.

19 - MANDRAS, A., VANINI, G. C., CIARLINI, E. - La reazione di immunofluorescenza per la dimostrazione degli anticorpi contro Toxoplasma gondii - L'Igiene Moderna 55: 636, 1962.

20 - NERY-GUIMARĀES, F., GRYNBERG, N., LAGE, H. A., VENANCIO, I. A. - Reacão indireta de anticorpos fluorescentes no diagnóstico da Toxoplasmose. - J. Bras. Med. 15: 89, 1968.

$21-$ SABIN, A. B., FELDMAN, H. A. Dyes as microchemical indicators of a new immunity phenomenon affecting a protozoon parasit (Toxoplasma) - Science 108: 660, 1948.

22 - SABIN, A. B., EICHENWALD, H., FELDMAN, H. A., JACOBS, L. Present status of clinical manifestation of Toxoplasmosis in man. Indications and provisions for routine serologic diagnosis - J.A.M.A. 150: 1063, 1952 .
23 - SULZER, A. J.. HALL. E. C. - Indirect fluorescent antibody test for parasitic diseases. IV Statistical study of variation in the indirect fluorescent antibody (IFA) test for Toxoplasmosis - Amer. J. Epidem. 86: 401. 1967 .

24 - SUUKI, K., SUTO, T., FUUITA, J. - Serological diagnosis of toxoplasmosis by the indirect immunofluorescent staining _- Nat. Inst. Anim. Ilth. Quart. 5: 73, 1965

25 - TAKUMI, K., TAKEBAXASHI, I., TAKEUCHI, $H$. IKEDA, H. TOSHIOKA, N. - The use of lyophilized parasites in indirect fluorescent antibody technique for detection of toxoplasma antibody. - Japan. J. Microbiol, 10: 189, 1966

26 - VAN NUNEM, M. C. J., VAN DER VEEN, J. - Examination for toxoplasmosis by the fluorescent antibody technique - Trop. Geogr. Med. 17: 246,1965 .

27 - WALTON, B. C., BENCHOFF, B. M. BROOKS, W. $\mathbf{H}$. Comparison of the indirect fluorescent antibody test and methylene blue dye test for detection of antibodies Toxoplasma gondii, Amer. J. Trop. Med. Hyg. 15: $149,1966$.

28 - WELLER, T. H., COONS, A. H. Fluorescent antibody studies with agents of varicella and herpes zooster propagated in vitro. Proc. Soc. Exp. Biol. Med. 86: 789, 1954.

29 - WERY, M. - Indications de l'immunofluorescence dans la Toxoplasmose clinique et experimentale - Ann. Soc. Belge Med. Trop. 45: 541, 1965.

30 - ZARDI, O. - Gli anticorpi fluorescenti nella diagnostica per la toxoplasmosi - Nuovi Ann. d'Igiene e Microbiol. 14: 585, 1963. 